\title{
Analysis the Brachistochronic Motion of A Mechanical System with Nonlinear Nonholonomic Constraint
}

\author{
Radoslav D. Radulović \\ Teaching Assistan \\ University of Belgrade \\ Faculty of Mechanical Engineering \\ Dragomir N. Zeković \\ Full Professor \\ University of Belgrade \\ Faculty of Mechanical Engineering \\ Mihailo P. Lazarević \\ Full Professor \\ University of Belgrade \\ Faculty of Mechanical Engineering \\ Štefan Segl'a \\ Professor \\ Technical University of Košice \\ Faculty of Mechanical Engineering \\ Košice \\ Slovakia \\ Bojan M. Jeremić \\ Teaching Assistant \\ University of Belgrade \\ Faculty of Mechanical Engineering
}

This paper analyzes the problem of brachistochronic planar motion of a mechanical system with nonlinear nonholonomic constraint. The nonholonomic system is represented by two Chaplygin blades of negligible dimensions, which impose nonlinear constraint in the form of perpendicularity of velocities. The brachistrochronic planar motion is considered, with specified initial and terminal positions, at unchanged value of mechanical energy during motion. Differential equations of motion, where the reactions of nonholonomic constraints and control forces figure, are obtained on the basis of general theorems of mechanics. Here, this is more convenient to use than some other methods of analytical mechanics applied to nonholonomic mechanical systems, where a subsequent physical interpretation of the multipliers of constraints is required. The formulated brachistochrone problem, with adequately chosen quantities of state, is solved as simple a task of optimal control as possible in this case by applying the Pontryagin maximum principle. The corresponding two-point boundary value problem of the system of ordinary nonlinear differential equations is obtained, which has to be numerically solved. Numerical procedure for solving the two-point boundary value problem is performed by the method of shooting. On the basis of thus obtained brachistochronic motion, the active control forces, along with the reactions of nonholonomic constraints, are defined. Using the Coulomb friction laws, a minimum required value of the coefficient of sliding friction is defined, so that the considered system is moving in accordance with nonholonomic bilateral constraints

Keywords: Brachistochrone, Nonlinear nonholonomic constraint, Pontryagin's maximum principle, Coulomb friction, Optimal control.

\section{INTRODUCTION}

This paper analyzes the problem of brachistochronic planar motion of a mechanical system with nonlinear nonholonomic constraint. The brachistrochronic planar motion is considered, with specified initial and terminal positions, at unchanged value of mechanical energy during motion.

Differential equations of motion, where the reactions of nonholonomic constraints and control forces figure, are obtained on the basis of general theorems of mechanics.

The formulated brachistochrone problem, with adequately chosen quantities of state, is solved as simple a task of optimal control as possible in this case by applying the Pontryagin maximum principle. The corresponding two-point boundary value problem of the system of ordinary nonlinear differential equations is obtained, which has to be numerically solved. Numerical procedure for solving the two-point boundary value problem is performed by the method of

Received: April 2014, Accepted: October 2014

Correspondence to: Radoslav Radulovic

Faculty of Mechanical Engineering,

Kraljice Marije 16, 11120 Belgrade 35, Serbia

E-mail: rradulovic@mas.bg.ac.rs

doi:10.5937/fmet1404290R

(C) Faculty of Mechanical Engineering, Belgrade. All rights reserved shooting. On the basis of thus obtained brachistochronic motion, the active control forces, along with the reactions of nonholonomic constraints, are defined.

Using the Coulomb friction laws, a minimum required value of the coefficient of sliding friction is defined, so that the considered system is moving in accordance with nonholonomic bilateral constraints.

\section{DESCRIPTION OF THE DYNAMIC MODEL OF NONLINEAR NONHOLONOMIC SYSTEM}

In order to develop differential equations of motion of a dynamic model of nonlinear nonholonomic mechanical system (henceforth referred to as 'the system'), as well as for the needs of further considerations, two Cartesian reference coordinate systems must be first introduced.

The stationary coordinate system $O x y z$, whose coordinate plane $O x y$ coincides with the horizontal plane of motion, and the non-stationary coordinate system $A \xi \eta \varsigma$ attached rigidly to the considered system, so that the coordinate plane $A \xi \eta$ coincides with the plane $O x y$ (see Fig. 1).

The axis of the non-stationary coordinate system $A \xi$ is defined by the direction $A B$, that is, $B \in A \xi$, whereas unit vectors of the non-stationary 
coordinate system axes are $\vec{\lambda}, \vec{\mu}$ and $\vec{v}$, respectively. The system is composed of two Chaplygin blades [3], of negligible masses and dimensions, which impose constraint to the motion of particles $A$ and $B$, of equal masses $m$, in the form of perpendicularity of the velocities, as shown in Fig. 1.

Particles $A$ and $B$ are interconnected by a light forkslike structure, which allows the distance $\overline{A B}=\xi \neq$ const. to change.

The configuration of the considered system relative to the system Oxyz is defined by a set of Lagrangian coordinates $\left(q^{1}, q^{2}, q^{3}, q^{4}\right)$, where $q^{1}=x$ and $q^{2}=y$ are Cartesian coordinates of the point $A, q^{3}=\varphi$ is the angle between the axis $O x$ and axis $A \xi$, while $q^{4}=\xi$ is the relative coordinate of point $B$ relative to the nonstationary coordinate system.

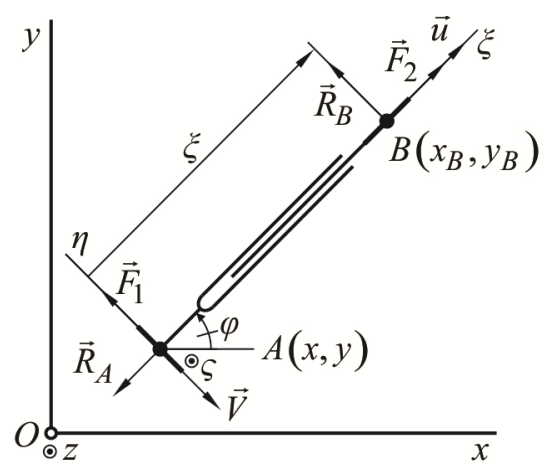

Figure 1. Nonlinear nonholonomic mechanical system

Further analysis relates to the case when the motion of point $A$ is constrained in the $A \xi$ axis direction, while the motion of point $B$ is constrained in the $A \eta$ axis direction, that is, lateral slipping of the points $A$ and $B$ of the system is not permissible in the $A \xi$ and $A \eta$ axis directions respectively.

Due to the imposed constraints to the motion, there occur horizontal reactions of nonholonomic constraints at the contact points of the $A$ and $B$ points and horizontal plane of motion $\vec{R}_{A}=-R_{A} \vec{\lambda}$ and $\vec{R}_{B}=R_{B} \vec{\mu}$ respectively.

In accordance with the constrained motion in the form of perpendicularity of the velocities of points $A$ and $B$, the nonholonomic nonlinear homogeneous constraint has the form [3], [4]

$$
\vec{V} \cdot \vec{u}=0 \Rightarrow \dot{x} \dot{x}_{B}+\dot{y} \dot{y}_{B}=0,
$$

where $\vec{V}$ and $\vec{u}$ are the velocities of points $A$ and $B$ respectively.

Taking into account that the motion of point $A$ is constrained in the $A \xi$ axis irection, the second nonholonomic homogeneous constraint can be represented in the form as follows

$$
\dot{x} \cos \varphi+\dot{y} \sin \varphi=0,
$$

and, as a result, the velocity $\vec{V}$, of point $A$, has the $A \eta$ axis direction, that is

$$
V=\dot{x} \sin \varphi-\dot{y} \cos \varphi,
$$

where $V=\vec{V} \cdot \vec{\mu}$. The coordinates of point $B$ relative to the coordinate system $O x y z$ are

$$
x_{B}=x+\xi \cos \varphi, \quad y_{B}=y+\xi \sin \varphi, \quad z_{B}=0 .
$$

Now, based on nonholonomic constraints (1) and (2), taking into account the relations (3) and (4), the angular velocity of the system is determined in the form

$$
\dot{\varphi}=\frac{V}{\xi} .
$$

The velocity $\vec{u}$, of point $B$, which has the $A \xi$ axis direction can be expressed, based on relations (2) and (4), in the form as follows

$$
u=\dot{\xi}
$$

where $u=\vec{u} \cdot \vec{\lambda}$.

As it is well-known, the realization of the brachistochronic motion of mechanical systems can be left, in general, to the control forces, whose total power equals zero during brachistochronic motion, which can be represented in the form of active control forces, then by the forces of reactions of the constraints or by their mutual combinations.

For this case, the realization of the brachistochronic motion is achieved by active control forces $\vec{F}_{1}=F_{1}(t) \vec{\mu}$ and $\vec{F}_{2}=F_{2}(t) \vec{\lambda}$ acting at the points $A$ and $B$ respectively, whose power equals zero during the brachistochronic motion

$$
P^{G}=\vec{F}_{1} \cdot \vec{V}+\vec{F}_{2} \cdot \vec{u}=0,
$$

that is

$$
-F_{1} V+F_{2} u=0 .
$$

Differential equations of motion will be developed based on the general theorems of dynamics $[6,8,10]$, that is, by applying the theorem of change in momentum of a mechanical system, as well as the theorem of change in moment of momentum of a mechanical system for the moving point $A$,

$$
\begin{aligned}
& \frac{d \vec{K}}{d t}=\vec{F}_{R}^{s}, \\
& \frac{d \vec{L}_{A}}{d t}+\vec{V}_{A} \times \vec{K}=\vec{M}_{A}^{s} .
\end{aligned}
$$

The vector equations (9) have respectively the following, corresponding scalar equations relative to the axes of defined non-stationary coordinate system $A \xi \eta \zeta$

$$
\begin{aligned}
& \xi \rightarrow m(V \dot{\varphi}+\dot{u})=F_{2}-R_{A}, \\
& \eta \rightarrow-m \ddot{\varphi} \xi=F_{1}+R_{B}, \\
& \zeta \rightarrow 0 \equiv 0, \\
& \xi \rightarrow 0 \equiv 0 \\
& \eta \rightarrow 0 \equiv 0 \\
& \zeta \rightarrow m V u=R_{B} \xi .
\end{aligned}
$$


Solving the system of equations (8) and (10), the reactions of nonholonomic constraints, as well as control forces, are defined to realize the brachistochronic motion, as a function of defined quantities of state and corresponding derivatives

$$
\begin{aligned}
& R_{A}=-m\left(\frac{V}{u} \xi \ddot{\varphi}+2 V \dot{\varphi}+\dot{u}\right), \\
& R_{B}=m \dot{\varphi} u, \\
& F_{1}=-m(\xi \ddot{\varphi}+\dot{\varphi} \dot{\xi}), \\
& F_{2}=-m V\left(\frac{\xi}{u} \ddot{\varphi}+\dot{\varphi}\right) .
\end{aligned}
$$

During the system brachistochronic motion, the law of the conservation of mechanical energy holds

$$
\Phi(V, u)=V^{2}+u^{2}-\frac{2 T_{0}}{m}=0
$$

where $T_{0}$ is the kinetic energy of the system at initial time moment $t_{0}=0$.

\section{BRACHISTOCHRONIC MOTION AS THE PROBLEM OF OPTIMAL CONTROL}

This section involves the definition of the problem of brachistochronic motion of the system as the problem of optimal control.

The equations of state that describe the motion of the considered system in the state space can be defined in the form

$$
\begin{aligned}
& \dot{x}=V \sin \varphi, \quad \dot{y}=-V \cos \varphi, \\
& \dot{\varphi}=\frac{V}{\xi}, \quad \dot{\xi}=u .
\end{aligned}
$$

The coordinates of initial state $x, y, \varphi$ and $\xi$, as well as the kinetic energy, are defined at the initial position of the system on manifolds:

$$
\begin{aligned}
& t_{0}=0, \quad x\left(t_{0}\right)=0, \quad y\left(t_{0}\right)=0, \quad \varphi\left(t_{0}\right)=0, \\
& \xi\left(t_{0}\right)=a, \quad V^{2}\left(t_{0}\right)+u^{2}\left(t_{0}\right)-\frac{2 T_{0}}{m}=0,
\end{aligned}
$$

as well as the coordinates of end state $x, y, \varphi$ and $\xi$ at the terminal position of the system on manifolds:

$$
\begin{aligned}
& t=t_{1}, \quad x\left(t_{1}\right)=a, \quad y\left(t_{1}\right)=b, \\
& \varphi\left(t_{1}\right)=\varphi_{1}, \quad \xi\left(t_{1}\right)=2 a,
\end{aligned}
$$

where $t_{1}$ is the value unknown in advance of the final time moment that corresponds to the end state of the system on manifolds (15).

The brachistochrone problem of the motion of the system described by equations of state (13) consists in determining the coordinates of optimal control $V$ and $u$, as well as their corresponding coordinates of state $x, y, \varphi$ and $\xi$, so that the system starting from the initial state on manifolds (14), moves to the end state on manifolds (15), with unchanged value of mechanical energy (12), in a minimum time.
This can be expressed in the form of condition, so that the functional

$$
I=\int_{t_{0}}^{t_{1}} d t
$$

in the interval $\left[t_{0}, t_{1}\right]$ has a minimum value.

For the purpose of solving the problem of optimal control, defined by the Pontryagin maximum principle [1], the Pontryagin function is developed in the form as follows

$$
\begin{aligned}
& H=\lambda_{0}+\lambda_{x} V \sin \varphi-\lambda_{y} V \cos \varphi+\lambda_{\varphi} \frac{V}{\xi}+\lambda_{\xi} u \\
& +\mu \Phi(V, u)
\end{aligned}
$$

where $\lambda_{0}=$ const. $\leq 0, \lambda_{x}, \lambda_{y}, \lambda_{\varphi}$ and $\lambda_{\xi}$ are coordinates of the conjugate vector, where it can be taken that $\lambda_{0}=-1$, while $\mu$ is a multiplier corresponding to the relation (12). Taking into account the boundary conditions (14) and (15), as well as the fact that time does not figure explicitly in equations of state (13), the defined problem of optimal control can be solved by a straightforward application of Theorem 3, that is, Theorem 1 [1].

Based on the Pontryagin function (17), the conjugate system of differential equations has the form

$$
\begin{aligned}
& \dot{\lambda}_{x}=0, \quad \dot{\lambda}_{y}=0, \\
& \dot{\lambda}_{\varphi}=-V\left(\lambda_{x} \cos \varphi+\lambda_{y} \sin \varphi\right), \quad \dot{\lambda}_{\xi}=\frac{V}{\xi^{2}},
\end{aligned}
$$

where from it follows that $\lambda_{x}=$ const. and $\lambda_{y}=$ const..

Taking into account that the initial state (14), as well as the end state (15), is completely determined, the transversality conditions are identically satisfied.

If controls belong to an open set, as in this case, the conditions for determining optimal control can be expressed in the form

$$
\left(\frac{\partial H}{\partial u_{i}}\right)_{\boldsymbol{u}^{o p t}}=0,\left(\frac{\partial^{2} H}{\partial u_{i} \partial u_{j}}\right)_{\boldsymbol{u}^{o p t}} u_{i} u_{j} \leq 0,(i, j=1,2) .
$$

When time $t_{1}$ is not determined in advance, as in this case, in solving the system of equations (13) and (18) in the final form, the condition should be added, following a straightfoward application of Theorem 1 [1], that the value of the Pontryagin function on the optimal trajectory equals zero for $\forall t \in\left[t_{0}, t_{1}\right]$

$$
H(t)=0 \text {, }
$$

that is, in accordance with the relation (17)

$$
\begin{aligned}
& -1+\lambda_{x} V \sin \varphi-\lambda_{y} V \cos \varphi+\lambda_{\varphi} \frac{V}{\xi}+\lambda_{\xi} u \\
& +\mu \Phi(V, u)=0 .
\end{aligned}
$$


Now, and based on (17), (19) and (21), the value of a multiplier $\mu$ is determined, as well as the control functions $V$ and $u$ in the form as follows

$$
\begin{aligned}
& \mu=-\frac{1}{4 T_{0}}, V=\frac{2 T_{0}}{m}\left(\lambda_{x} \sin \varphi-\lambda_{y} \cos \varphi+\frac{1}{\xi} \lambda_{\varphi}\right), \\
& u=\frac{2 T_{0}}{m} \lambda_{\xi} .
\end{aligned}
$$

Based on condition (20) defined at the initial time moment, as well as (14), (17) and (22), the conjugate vector coordinate $\lambda_{\varphi}$ is determined at the initial time moment

$$
\lambda_{\varphi}\left(t_{0}\right)_{1 / 2}=\xi\left(t_{0}\right)\left(\lambda_{y} \pm \sqrt{\frac{m}{2 T_{0}}-\lambda_{\xi}^{2}\left(t_{0}\right)}\right),
$$

where from a global estimate for the coordinate $\lambda_{\xi}\left(t_{0}\right)$ can be given

$$
-\sqrt{\frac{m}{2 T_{0}}} \leq \lambda_{\xi}\left(t_{0}\right) \leq \sqrt{\frac{m}{2 T_{0}}} .
$$

Now, based on (13), (18) and (22), the basic and conjugate system of differential equations can be created in the form

$$
\begin{aligned}
& \dot{x}=\frac{2 T_{0}}{m}\left(\lambda_{x} \sin \varphi-\lambda_{y} \cos \varphi+\frac{1}{\xi} \lambda_{\varphi}\right) \sin \varphi, \\
& \dot{y}=-\frac{2 T_{0}}{m}\left(\lambda_{x} \sin \varphi-\lambda_{y} \cos \varphi+\frac{1}{\xi} \lambda_{\varphi}\right) \cos \varphi \\
& \dot{\varphi}=\frac{2 T_{0}}{m}\left(\lambda_{x} \sin \varphi-\lambda_{y} \cos \varphi+\frac{1}{\xi} \lambda_{\varphi}\right) \frac{1}{\xi}, \\
& \dot{\xi}^{\prime}=\frac{2 T_{0}}{m} \lambda_{\xi} \\
& \dot{\lambda}_{x}=0, \\
& \dot{\lambda}_{y}=0, \\
& \dot{\lambda}_{\varphi}=-\frac{2 T_{0}}{m}\left(\lambda_{x} \sin \varphi-\lambda_{y} \cos \varphi+\frac{1}{\xi} \lambda_{\varphi}\right) \\
& \cdot\left(\lambda_{x} \cos \varphi+\lambda_{y} \sin \varphi\right), \\
& \dot{\lambda}_{\xi}=\frac{2 T_{0}}{m}\left(\lambda_{x} \sin \varphi-\lambda_{y} \cos \varphi+\frac{1}{\xi} \lambda_{\varphi}\right) \lambda_{\varphi} \frac{1}{\xi^{2}} .
\end{aligned}
$$

Numerical procedure for solving the corresponding two-point boundary value problem of the system of ordinary nonlinear differential equations of the first kind (25), based on the known initial state (14) and (23), as well as end state (15), is grounded on the method of shooting [2]. The four-parameter shooting consists of determining unknown coordinates of the conjugate vector $\lambda_{x}, \lambda_{y}$ and $\lambda_{\xi}\left(t_{0}\right)$, as well as a minimum required time $t_{1}$.

The procedure of numerical determination of the unknown parameters consists of 'shooting' the end-state coordinates (15), at the known initial state (14) and (23). The application of shooting method requires an estimate for the interval of parameters' values being determined [10]. On the basis of estimates for the values of the conjugate vector coordinates $\lambda_{\xi}\left(t_{0}\right)$, given in (24), it can be claimed that all solutions to the corresponding two-point boundary value problem are certainly located within the interval given, thereby the global minimum time in the brachistochronic motion of the system.

For a concrete case, the estimate for the values of coordinates $\lambda_{x}$ and $\lambda_{y}$ cannot be given, so all solutions satisfying the maximum principle should be found. For the case of multiple solutions to the maximum principle, global minimum is the one corresponding to the minimum time.

The two-point boundary value problem is solved for the values of the parameters as follows

$$
T_{0}=2 \frac{\mathrm{kgm}^{2}}{\mathrm{~s}^{2}}, m=2 \mathrm{~kg}, a=1 \mathrm{~m}, \varphi_{1}=\pi / 2 \mathrm{rad} .
$$

In accordance with (16), the time of the brachistochronic motion of the system, as well as the conjugate vector coordinates for the given values of parameters (26) are $t_{1}=1.7259 \mathrm{~s}, \lambda_{x}=-1.0941 \mathrm{~s} / \mathrm{m}, \lambda_{y}=-1.6746 \mathrm{~s} / \mathrm{m}$ and $\lambda_{\xi}\left(t_{0}\right)=0.2057 \mathrm{~s} / \mathrm{m}$.

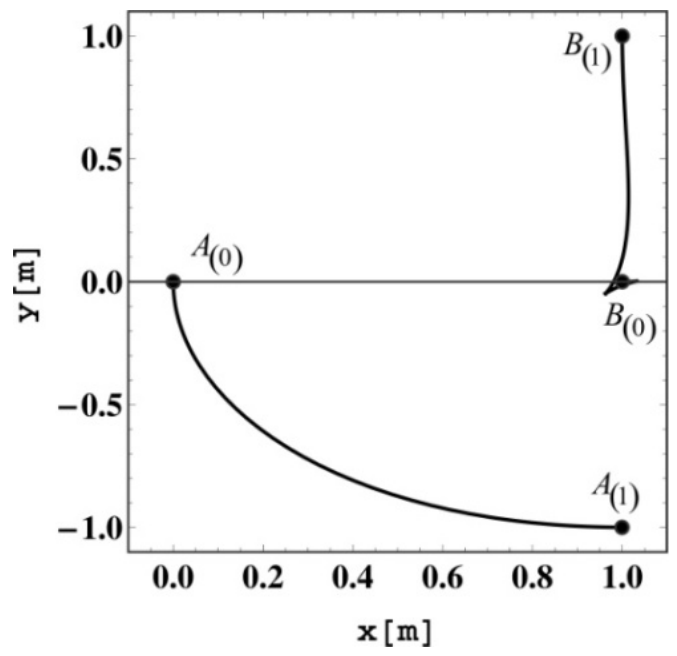

Figure 2. Trajectories of points $A$ and $B$.

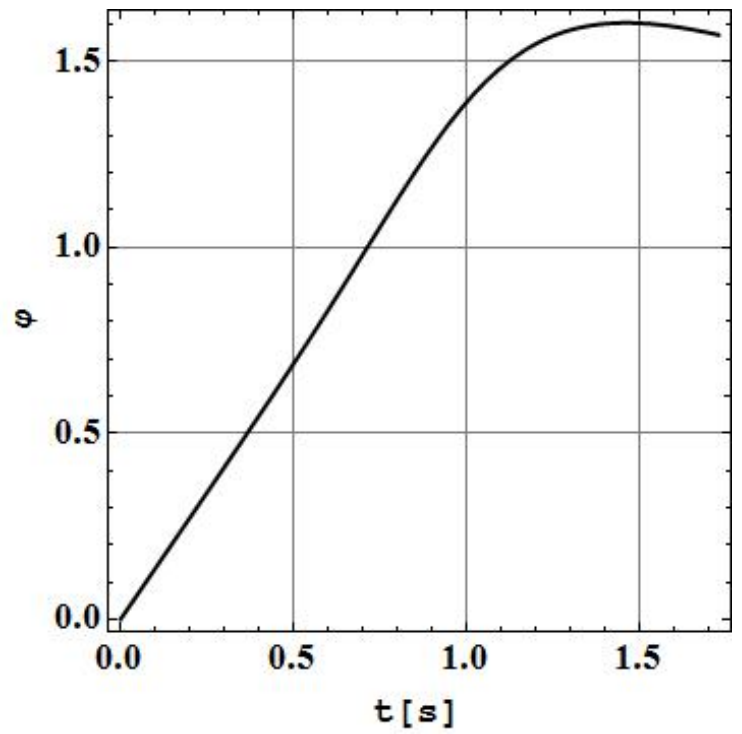




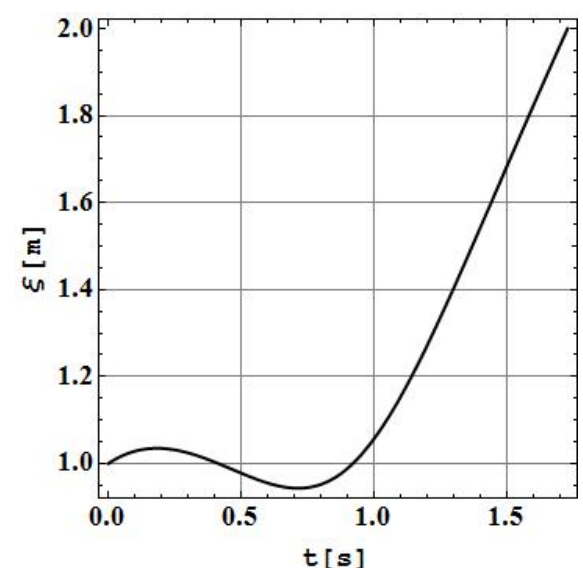

Figure 3. Graphs of angle $\varphi$ and relative coordinate $\xi$.
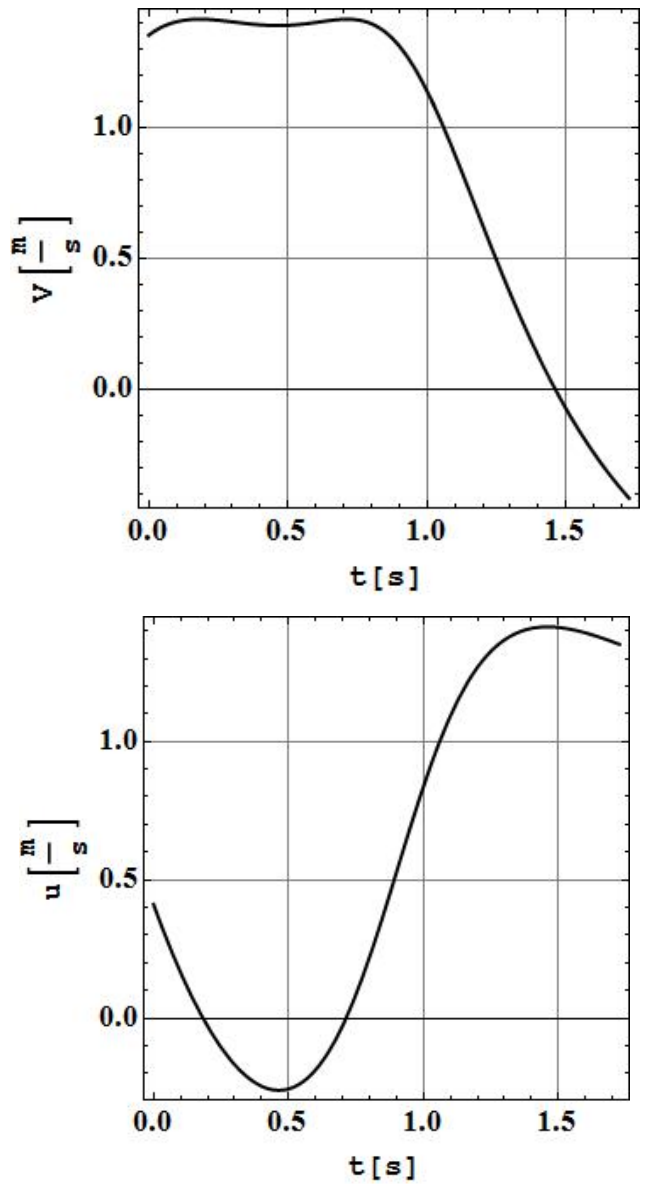

Figure 4. Graphs of control functions $V$ and $u$.

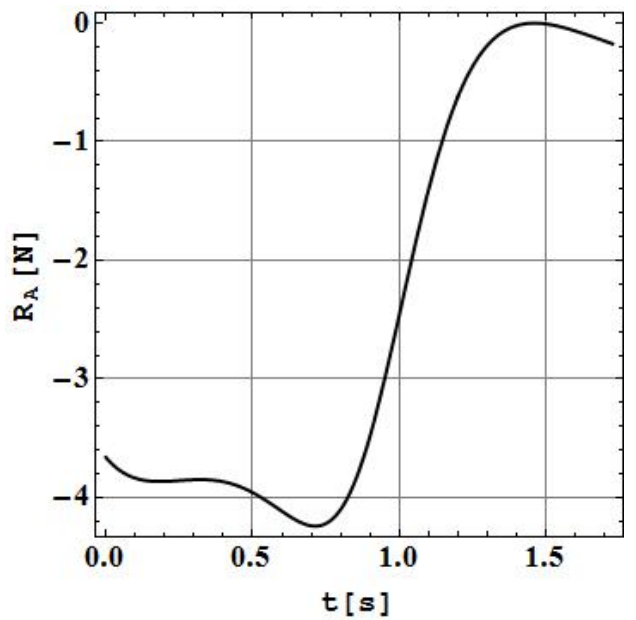

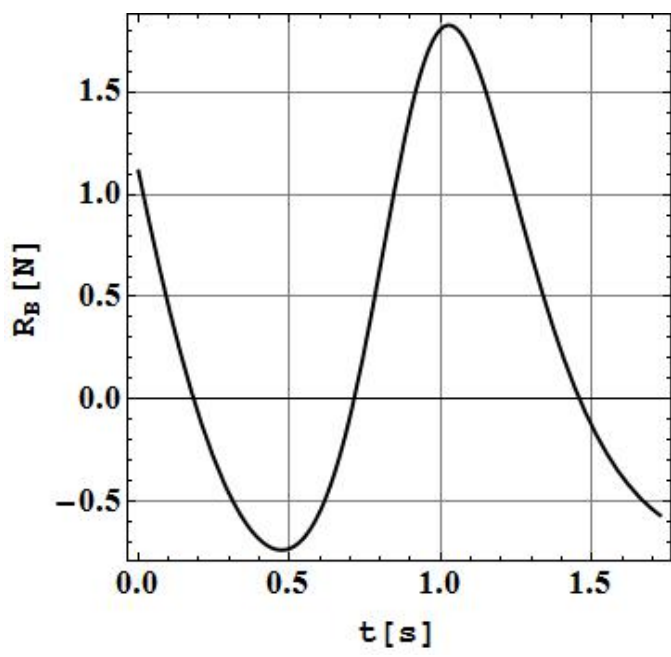

Figure 5. Graphs of reactions of nonholonomic constraints $R_{A}$ and $R_{B}$.
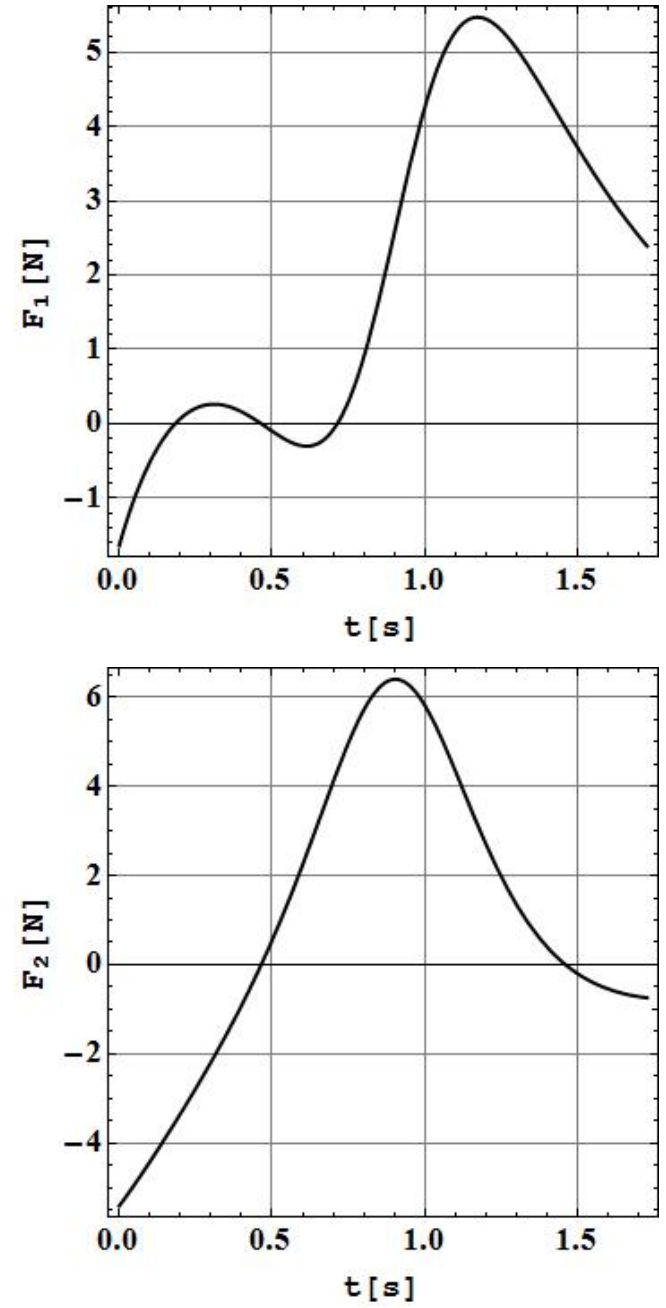

Figure 6. Graphs of control forces $F_{1}$ and $F_{2}$.

\section{DYNAMIC CONDITIONS FOR REALIZING THE BRACHISTOCHRONIC MOTION}

Differential equations of motion of the system (10), that is, the reactions of nonholonomic constraints and control forces as well (11), are obtained in accordance with restrictions (1) and (2). 
Taking this into account, the necessary dynamic conditions for realizing the motion of the system in accordance with restrictions (1) and (2) $[9,10]$, based on the Coulomb friction laws, are that intensities of the interaction forces between points $A$ and $B$ of the system and the horizontal plane of motion should not exceed the corresponding Coulomb forces of sliding friction.

The interaction force between point $A$ of the system and the horizontal plane of motion is defined by the vector sum of the control force $\vec{F}_{1}$ and the reaction force of nonholonomic constraint $\vec{R}_{A}$, so that, in accordance with (6), the necessary dynamic condition for realizing the defined motion of point $A$ of the system can be written in the form of inequality

$$
F_{A}=\sqrt{F_{1}^{2}+R_{A}^{2}}<F_{A}^{f r}=\mu_{A} N_{A},
$$

where $F_{A}^{f r}$ and $\mu_{A}$ are the friction force and the sliding friction coefficient between point $A$ of the system and the horizontal plane of motion, whereas $N_{A}$ is normal reaction of the plane of motion of point $A$ of the system. Analogously to what has been above mentioned for point $A$ of the system, the necessary dynamic condition for point $B$ of the system can be written in the form as follows

$$
F_{B}=\sqrt{F_{2}^{2}+R_{B}^{2}}<F_{B}^{f r}=\mu_{B} N_{B} .
$$

Normal reactions of the horizontal plane of motion of points $A$ and $B$ of the system are $N_{A}=N_{B}=19.61 \mathrm{~N}$. The diagrams below, based on previous considerations, show the laws of change of minimum required values of the sliding friction coefficients $\mu_{A}$ and $\mu_{B}$.
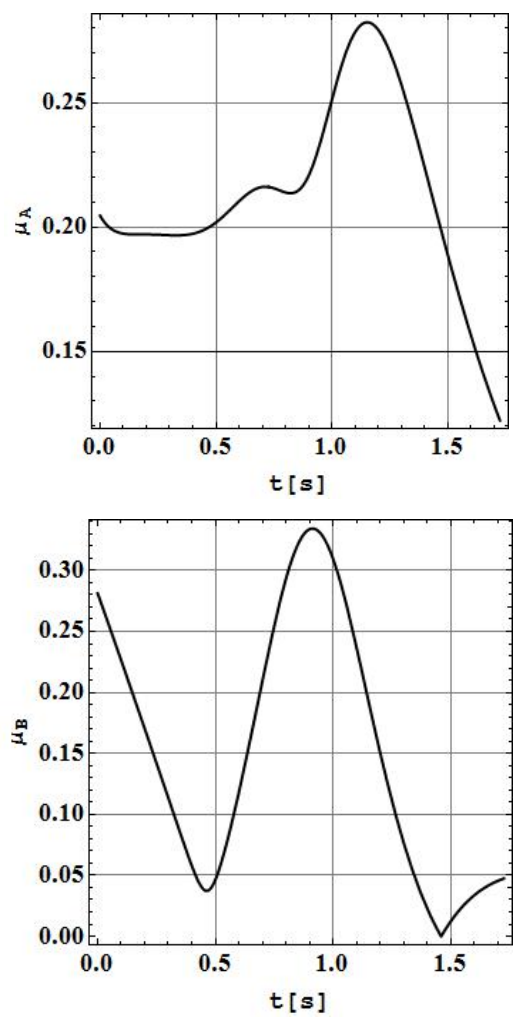

Figure 7. Graphs of minimum required sliding friction coefficients $\mu_{A}$ and $\mu_{B}$.
Minimum required value of the sliding friction coefficient between point $A$ of the system and the horizontal plane of motion, based on (27), is $\mu_{A}^{*}=\mu_{A}(t=1.153 \mathrm{~s})=0.282$, whereas minimum required value for point $B$ of the system, based on (28), is $\mu_{B}^{*}=\mu_{B}(t=0.913 \mathrm{~s})=0.334$.

Combining the necessary dynamic conditions (27) and (28) to realize the defined brachistochronic motion in accordance with restrictions (1) and (2), it is clearly deduced that minimum required value of the sliding friction coefficient is $\mu^{*}=\mu_{B}^{*}=0.334$.

\section{CONCLUSIONS}

This paper considers the brachistochronic planar motion of the mechanical system with nonlinear nonholonomic constraint, with specified initial and terminal positions, at unchanged value of mechanical energy. The procedure for developing differential equations of motion of the system based on the general theorems of mechanics is presented.

The formulated brachistochrone problem, with adequately chosen quantities of state, is solved as the simplest task of optimal control by applying the Pontryagin maximum principle. The conducted numerical procedure for solving the two-point boundary value problem is grounded on the shooting method. Afterwards, the reactions of nonholonomic constraints, as well control forces, are defined to realize the brachistochronic motion. Using the Coulomb friction laws, a minimum required value of the sliding friction coefficient between the horizontal plane of motion and the considered system is defined.

The authors consider that the results obtained in this work can be extended to the case when the sliding friction coefficients are below minimum required values. In that case, when the control forces are constrained, the task of optimal control becomes considerably more complex, which is the subject of future investigations.

\section{ACKNOWLEDGMENT}

Authors gratefully acknowledge the support of Ministry of Education, Science and Technological Development of the Republic of Serbia under the project ON 17400 and TR 35006.

\section{REFERENCES}

[1] Pontryagin, L.S., Boltyanskii, V.G., Gamkrelidze, R.V. and Mishchenko, E.F.: The Mathematical Theory of Optimal Processes, Wiley, New Jersey, 1962.

[2] Stoer, J., and Bulirsch, J.: Introduction to Numerical Analysis, Second ed. Springer, New York and London, 1993.

[3] Zeković, D.: Dynamics of mechanical systems with nonlinear nonholonomic constraints - I The history of solving the problem of a material realization of a nonlinear nonholonomic constraint, ZAMM $\cdot Z$. Angew. Math. Mech. 91, No. 11, 883 - 898, 2011. 
[4] Zeković, D.: Examples of nonlinear nonholonomic constraints in Classical mechanics, Vestnik Mosk. Un-ta, Ser. 1, Mat.-Meh. 1, 100-103, 1991.

[5] Chaplygin, S. A.: On the theory of motion of nonholonomic systems, 2008. The reducingmultiplier theorem. Mathematical Collection. 28(1), 303-314, 1911. English Translation by A. V. Getling. Regular and Chaotic Dynamics. 13(4), 369-376.

[6] Šalinić, S., Obradović, A., Mitrović, Z. and Rusov, S.: On the brachistochronic motion of the Chaplygin sleigh. Acta Mechanica, ACME-D-1200149R1, 2013.

[7] Obradović, A., Čović, V., Vesković, M. and Dražić, M.: Brachistochronic motion of a nonholonomic rheonomic mechanical system, Acta Mech., 214 (34), pp. 291-304, 2010.

[8] Pars, L.A.: Treatise on analytical dynamics, Heinemann, London, 1968.

[9] Soltakhanov, Sh. Kh., Yushkov, M.P. and Zegzhda, S.A.: Mechanics of non-holonomic systems, Berlin: Springer-Verlag, 2009.

[10] Radulović, R., Obradović, A., Jeremić, B.: Analysis of the minimum required coefficient of sliding friction at brachistochronic motion of a nonholonomic mechanical system, FME Transactions, Vol. 42 No 3, pp. 201-206, 2014.

[11] Čović, V. and Vesković, M.: Brachistochronic motion of a multibody system with Coulomb friction, Eur. J. Mech. A, Solids 28(9), pp. 882 890, 2009.

[12] Šalinić, S., Obradović, A. and Mitrović, Z.: On the brachistochronic motion of mechanical system with unilateral constraints, Mechanics Research Communications, 45, pp. 1-6, 2012.

\section{АНАЛИЗА БРАХИСТОХРОНОГ КРЕТАҢА МЕХАНИЧКОГ СИСТЕМА СА НЕЛИНЕАРНОМ НЕХОЛОНОМНОМ ВЕЗОМ}

Радослав Радуловић, Драгомир Зековић, Михаило Лазаревић, Штефан Сегл’а, Бојан Јеремић

У овом раду анализира се проблем брахистохроног равног кретања механичког система са нелинеарном нехолономном везом. Нехолономни механички систем је представљен са два Чапљигинова сечива, занемарљивих димензија, која намећу нелинеарно ограничење у виду управности брзина. Разматра се брахистхроно равно кретање при задатом почетном и крајњем положају уз неизмењену вредност механичке енергије у току кретања. Диференцијалне једначине кретања, у којима фигуришу реакције нехолономних веза и управљачких сила, добијене су на основу општих теорема динамике. Овде је то подесније уместо неких других метода аналитичке механике примењених на нехолономне механичке системе у којима је неопходно дати накнадно физичко тумачење множитеља веза. Формулисан брахистохрони проблем, уз одговарајући избор величина стања је решен као, најједноставнији у овом случају, задатак оптималног управљања применом Понтруагин-овог принципа максимума. Добијен је одговарајући двотачкасти гранични проблем система обичних нелинеарних диференцијалних једначина који је неопходно нумерички решити. Нумерички поступак за решавање двотачкастог граничног проблема врши се методом шутинга. На основу тако добијеног брахистохроног кретања одређују се активне управљачке силе, а уједно и реакције нехолономних веза. Користећи Кулонове законе трења клизања, одређује се минимално потребна вредност коефицијента трења клизања, тако да се разматрани систем креће у складу са нехолономним задржавајућим везама. 